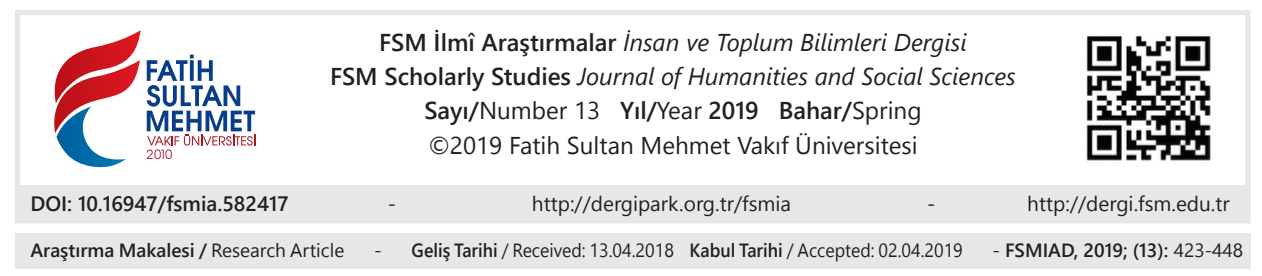

\title{
Anaokuluna Devam Eden Çocukların Değer Düzeylerinin Ebeveyn Görüşüne Göre Belirlenmesi
}

Hakan Şahin ${ }^{* *}$

\section{Öz}

$\mathrm{Bu}$ çalışma, anaokuluna devam eden beş-altı yaşındaki çocukların ebeveyn görüşlerine göre değer düzeylerinin belirlenmesini amaçlayan betimsel bir araştırmadır. Çalışmanın evrenini Ankara ilinde resmi anaokullarında eğitim gören beş-altı yaş gurubu 14.218 çocuk oluşturmuştur. Çalışma grubunu seçkisiz örnekleme yöntemlerinden tabakalı örneklem yöntemiyle seçilen beş yaştan 172, altı yaştan 202, toplamda 374 çocuk oluşturmaktadır. Araştırmada, araştırmacı tarafından geliştirilen "Aile Bilgi Formu” ve “Okul Öncesi Değerler Ölçeği Ebeveyn Formu” kullanılmıştır. Gruplar arasındaki farklılıklar incelenirken normal dağılımdan gelmeyen değişkenler için Mann Whitney U ve Kruskal Wallis-H testlerinden yararlanılmıştır. Kruskal Wallis-H Testinde anlamlı farklılıkların görülmesi durumunda Post-Hoc Çoklu Karşılaştırma Testi ile aralarında farklılık olan gruplar belirlenmiştir. Normal dağılımdan gelmeyen değişkenler arasındaki ilişkiler incelenirken Spearman's Korelasyon Katsayısından yararlanılmıştır. Sonuçlar yorumlanırken anlamlılık düzeyi olarak 0,05 kullanılmış olup; $\mathrm{p}<0,05$ olması durumunda anlamlı bir ilişkinin olduğu, $\mathrm{p}>0,05$ olması durumunda ise anlamlı bir ilişkinin olmadığı belirtilmiştir.

Araştırma sonucunda; çocukların sırasıyla en fazla sorumluluk, saygı, işbirliği, dürüstlük, dostluk/arkadaşlık ve paylaşım değerlerini edindikleri saptanmıştır. Ortanca ve son çocukların değer puanları ilk çocuklardan anlamlı derecede yüksek bulunmuştur. Öğ-

\footnotetext{
* $\quad$ Bu çalışmanın bir bölümü 5. Uluslararası Okul Öncesi Eğitim Kongresinde 2017 sözlü bildiri olarak sunulmuştur.

** Dr. Öğr. Üyesi, İstanbul Üniversitesi-Cerrahpaşa Hasan Ali Yücel Eğitim Fakültesi Okul Öncesi Öğretmenliği Bölümü, İstanbul/Türkiye, Hakansahin@istanbul.edu.tr, orcid.org/00000002-2787-6788
} 
renim düzeyleri yüksek olan ebeveynlerin çocuklarının değer puanları, öğrenim düzeyi düşük olan ebeveynlerin çocuklarının değer puanlarından yüksektir. Yüksek ve orta gelir grubunda olan çocukların puanlarının düşük gelir grubunda yer alan çocukların puanlarından anlamlı derecede yüksek bulunmuştur. Çocukların yaşı arttıkça değer edinim düzeyleri artmaktadır. Kardeş sayısı ve ebeveynlerin yaşlarıyla değer edinim düzeyleri arasında anlamlı bir ilişkinin olmadığı saptanmıştır.

Anahtar Kelimeler: Değer, değerler eğitimi, okul öncesi eğitim.

\title{
Determining the Value Levels of Children According to Parents Views
}

\begin{abstract}
This descriptive study aims to determine the value levels of children in the age group of five-six attending official kindergartens according to teacher views. Target population of the study consisted of 14.218 children in the age group of five-six attending official kindergartens in Ankara. Study group consisted of 172 children from the age group of five, 202 children from the age group of six and a total of 374 children who were selected with stratified sampling method, which is among random sampling methods. "Family Information Form" that was developed by the researcher and "Family's Form for Preschool Values Scale" that was developed were used in the study. Differences between the groups were examined by using Mann Whitney U and Kruskal Wallis-H tests for normally distributed variables. Groups that had significant differences in the Kruskal Wallis-H Test were determined by using Post-Hoc Multiple Comparison Test. Relations between the variables that were not normally distributed were examined by using Spearman's Correlation Coefficient.

As a result of the study; it was determined that children respectively adopted the values of; Responsibility, Respect, Cooperation, Honesty, Friendship and Sharing respectively. The Middle/median and the youngest children value scores were significantly higher than their first child. The Children with higher educated parents have higher value scores than the children with lower educated parents. The scores of children in the high and middle income groups were significantly higher than the scores of the children in the low income groups. As the children grow older the level of value acquisition increases. There was no significant relationship between the number of siblings and their parents' age.
\end{abstract}

Keywords: Value, values education, pre-school education. 


\section{Giriş}

Eğitimin toplumsal sorumluluğunu ifade eden değerleri benimseyen bireyler yetiştirmek toplumun, okulun ve ailenin en önemli vazifelerindedir. Bu düşüncelerden hareketle okulların asıl iki hedefinden söz etmek gerekir. Birincisi akademik becerilerinde başarılı olan aynı zamanda temel değerleri özümseyen bireylerin yetiştirilmesidir. ${ }^{1}$ İkincisi değerlerin bireylere aktarılmasıyla davranışlarında istendik değişimler de eğitimin hedefi olmakla birlikte değerlerin davranışa dönüşmesi sağlanmalıdır. Değerin bir anlam ifade etmesi için davranışa dönüşmesi gerekir. Bunu sağlamanın yolu da değerlerin özümsenmesiyle olabilir. Değerleri özümseyen birey için toplumsal baskı ve kavgalar en az düzeye iner ve birey edindiği bu değerlere uygun davranışlar sergiler. ${ }^{2}$

Aile, insan hayatının temel ve en önemli toplumsal kurumudur. Tüm toplumlar, öne çıkan değerlerini aile vasıtasıyla kuşaktan kuşağa aktarılar. Yaşadığımız toplumun kültürü bireyin kişiliğinin oluşmasında ve ahlaka dayalı bir karakter geliştirmede önemli bir yere sahiptir. ${ }^{3}$

Değerlerin ilk oluştuğu yer bireyin ailesidir. Bireylerin ailede kazandığı değerler ve çevrenin etkisiyle kazandığı değerler zamanla karakter haline dönüşmektedir. ${ }^{4}$ Bireylerin eğitimi, ailede başlar, eğitim kurumları ve sosyal çevrenin etkisiyle hayat boyu devam eder. Bireylere ahlaklı tutum ve davranışların aktarılması eğitimin en önemli görevlerindendir. ${ }^{5}$ Aile, çevresiyle sıkı bir ilişki içinde, toplumun genel yönelimlerini ve değerlerini kuşaktan kuşağa aktarmakla görevlidir. ${ }^{6}$

Bireyler, toplumun temel değerlerini çocukluk çağlarından başlayarak kazanmaya başlar. Önce aileden daha sonra da çevreden farklı yollarla kazanılmaya başlanan değerler, görsel ve yazılı araçlardan gözlem, model alma ve taklit gibi yöntemler ile kazanılmaya başlanır. ${ }^{7}$

1 Halil Ekşi, “Temel İnsani Değerlerin Kazandırılmasında Bir Yaklaşım: Karakter Eğitimi Programları", Değerler Ĕ̆itimi Dergisi, 1(1), 2003, s.79-96.

2 Keziban Tekşan, “Türkçe Dersi Değerler Eğitiminde Kutadgu Bilig 'in Kullanımı”, Ahi Evran Üniversitesi Kırşehir Eğitim Fakültesi Dergisi, 13(3), 2012, s.2-5.

3 Mehmet Zeki Aydın, “Ailede Ahlak Eğitimi”, Cumhuriyet Üniversitesi İlahiyat Fakültesi Dergisi, Cilt: VII 1 2, 2003, s. 125-158.

4 Gökmen Kutlutürk, Din Kültürü ve Ahlak Bilgisi 2 Ders Notu, Ankara, MEB Hayat Boyu Öğrenme Genel Müdürlüğ̈̈ Yayınları, 2012, s.12.

5 Mehmet Zeki Aydın, a,g,e., s.125.

6 Atalay Yörükoğlu, Çocuk Ruh Sağlı̆̆l, 5. bs., İstanbul, Türkiye İş Bankası Kültür Yayınları. 1983, s. 132.

7 Emine Kolaç, "Hacı Bektaş Velî Mevlana ve Yunus Felsefesiyle Türkçe Derslerinde Değerler ve Hoşgörü Eğitimi”, Türk Kültürü ve Hacı Bektaş Veli Araştırma Dergisi, (55), 2010, s. 194-196. 
Değerlerin kazandırılmasında en etkili ve kalıcı izler bırakan dönem erken çocukluk yıllarıdır. Bu nedenle aileye çok büyük sorumluluklar düşmektedir. Ebeveynler, çocuklarının değerleri edinmesindeki en önemli faktörlerden biridir. Değerler, insanların birbirinden etkilenerek model alarak ve zamanla bunu bir yaşam şekline dönüştürdükleri yaşam alışkanlıklarıdır. Aile bir ahlak okuludur ve değerler ilk burada kazanılmaya başlar. ${ }^{8}$

Değerler eğitiminin başlaması ailede model alma şeklinde başlayarak eğitim ortamlarından ve çevreden edinilen tecrübeyle gelişmektedir. Aile ortamında kazanılan alışkanlıkların sonraki yıllarda değişmesi imkânsız olmamakla birlikte çok zordur. Bu nedenle, çocuğun kişiliğinde silinmesi zor olan izler bırakan okul öncesi dönemde eğitim çok mühimdir. ${ }^{9}$

Bireylerin küçük yaşlarda kazandıkları değerlerin, bireyin aile, okul ve toplumsal yaşamını etkilemesi nedeniyle, okul döneminde müfredatta seçilen değerlerin etkili bir şekilde aktarılması çok önemlidir. Bu etkili aktarımın oluşması için öncelikle; eğitim kurumunun ebeveynler ile iş birliği içinde çalışması, çocukların değer kazanımlarının eğitimciler ve ebeveynleri tarafından izlenmesine ve bu konuda ebeveynlerin ve eğitimcilerin görüş birliğine bağlidır. ${ }^{10}$

Tüm bu araştırmalar doğrultusunda, okul öncesi dönem çocuklara; sevgi, sayg1, sorumluluk, işbirliği, yardımseverlik, hoşgörü, arkadaşlık, nezaket, öz denetim, paylaşma, dürüstlük gibi temel değerlerin kazandırılabileceği söylenebilir.

Değerler ile ilgili literatür incelendiğinde, okulöncesi dönemde verilen değerler eğitiminin bireyin ahlak yargısını geliştirdiği, doğruluk, dürüstlük, adalet gibi değerler kazandırdığı ve sosyal sorumluluk almayı öğrettiği görüşüdür. Ayrıca sürekli gelişen ve yenilenen dünyada bazı değerlerin giderek yitirildiği ve bu konuda okul öncesi yıllardan başlanarak eğitim verilmesi önemlidir. Eğitim vermeden önce çocuklarımızın bu değerlere ne kadar sahip olduğu önemlidir. $\mathrm{Bu}$ görüşlerden hareketle resmi anaokuluna devam eden çocukların sorumluluk, sayg1, işbirliği, dürüstlük, dostluk/arkadaşlık ve paylaşma değer düzeylerinin ebeveynlerin görüşlerine göre belirlenmesi amaçlanmıştır.

8 Ali Çankırılı, Ailede ve Okulda Değerler Eğitimi, İstanbul, Zafer Yayınları, 2015, s.40.

9 Hüseyin Yılmaz, "Çocuğun Ailede Kazanacağı Önemli Bir Değer: Kanaatkârlık", Eğitime Baklş Dergisi, (18), 2010, s.55-58.

10 İsmail Acun - Cemil Yücel- Ahmet Önder- Bülent Tarman, "Değerler: Kim ne kadar değer veriyor?”, Uşak Üniversitesi Sosyal Bilimler Dergisi, (12), 2013, s. 193-196. 


\section{Yöntem}

\section{Araştırmanın Modeli}

$\mathrm{Bu}$ araştırma, okul öncesi eğitim kurumlarına devam eden beş-altı yaş çocukların ebeveyn görüşlerine göre değer düzeylerinin belirlenmesini amaçlayan betimsel (Tarama Modelli) bir çalışmadır. Tarama modeli geçmişte ya da o anda var olan bir durumu var olduğu şekliyle betimleyen, tanımlamayı amaçlayan katılımcıların görüşlerinin, ilgi, beceri, yetenek, tutum, değer vb. özelliklerinin belirlendiği araştırma yaklaşımıdır. ${ }^{11}$

\section{Evren ve Örneklem}

Araştırmanın evrenini, Ankara İl Milli Eğitim Müdürlüğ̈̈’ne bağlı resmi anaokullarına devam eden beş-altı yaşındaki 14.218 çocuk oluşturmaktadır. Çalışma grubunda yer alan çocukların tamamı normal gelişim gösteren ve özel bir gereksinimi bulunmayan çocuklardır. Çalışma grubunu seçkisiz örnekleme yöntemlerinden tabakalı örneklem yöntemiyle 106 resmi bağımsız anaokulundan seçilen beş yaştan 172, altı yaştan 202, toplamda 374 çocuk oluşturmaktadır. Örneklem sayısı belirlenirken Çıngı tarafından uyarlanan tablo ölçüt alınmıştır. ${ }^{12}{ }^{13}$ Buna göre, 14.218 kişilik evrenden 0,05 sapma miktarı ve $a=0,05$ düzeyinde 374 kişi alınır. $\mathrm{Bu}$ araştırmada ise a=0,05 düzeyi seçilerek örneklem sayısı 374 olarak belirlenmiştir.

\section{Veri Toplama Araçları}

Araştırmada, araştırmacı tarafından geliştirilen 'Aile Bilgi Formu' ve Neslitürk ve Çeliköz tarafından geliştirilen "Okul Öncesi Değerler Ölçeği Aile Formu” kullanılmıştır.

Aile Bilgi Formu, Araştırmacı tarafından geliştirilmiş olup, çocukların yaşı, cinsiyeti kardeş sayısı, doğum sırası, babanın ve annenin yaşı, babanın ve annenin öğrenim durumu, ailenin sosyo-ekonomik düzeyi gibi bilgileri içeren sorulara yer verilmiş̧ir

Okul Öncesi Değerler Ölçeği: Okul Öncesi Değerler Ölçeği aile formu 30 maddeden oluşan Likert tarzı ölçektir. Ayrıca olumlu ve olumsuz maddelere yer verilmiştir. Oluşturulan maddelerde davranışı gösterme sıklık oranlarına göre 3 seçenek bulunmaktadır. Bu seçenekler; evet, bazen ve hayır şeklinde oluşturul-

11 Özkan Sapsağlam, Okul Öncesi Dönemde Karakter ve Değerler Ĕ̆itimi, editör Prof. Dr. Esra Ömeroğlu, Ankara, Pegem Akademi Yayınları, 2016.

12 Niyazi Karasar, Bilimsel Araştırma Metodu, Ankara, Hacetepe Taş Kitapçılık, 1984.

13 H. Çıngı, Örnekleme Kuramı, Beytepe, H.Ü. Fen Fakültesi Basımevi, 1994. 
muştur. Ölçeğin seçenekleri ve puanlanması şöyledir: Ölçeğin puanlamasında, evet ise 1 puan, bazen ise 2 puan, hayır ise 3 puan verilir. Olumsuz maddeler için ise ters puanlama yapılmıştır. Okul öncesi değer ölçeği aile formu güvenirliliği iç tutarlılık katsayısına göre incelenmiş, testi yarılama yöntemine dayalı olarak güvenirlik katsayısı aile formunun .84, Cronbach Alpha Güvenirlik sonuçlarına göre, ise .89 olarak hesaplanmıştır. ${ }^{14}$

\section{Verilerin Analizi}

Öncelikle çalışmanın örneklemine ilişkin demografik özelliklere ilişkin tanımlayıcı istatistikler hesaplanmıştır.

SPSS programı ile normalliğin dağılımını test etmek amacıyla Shapiro-Wilk testi uygulanmıştır. Yapılan analizlerin sonucunda; "Shapiro-Wilk" testinin "Sig." değerleri 0.05 ' den küçük olduğu için ölçek puanlarının normallik testi sonuçlarına göre, puanlar normal dağılımdan gelmemektedir $(\mathrm{p}<0,05)$.

Sonuçlar yorumlanırken anlamlılık düzeyi olarak 0,05 kullanılmıştır. Gruplar arasındaki farklılıklar incelenirken normal dağılımdan gelmeyen değişkenler için Mann Whitney U ve Kruskal Wallis-H Testlerinden yararlanılmıştır.

Kruskal Wallis-H Testinde anlamlı farkl1lıkların görülmesi durumunda PostHoc Çoklu Karşılaştırma Testi ile aralarında farklılık olan gruplar belirlenmiştir.

Normal dağglımdan gelmeyen değişkenler arasındaki ilişkiler incelenirken Spearman's Korelasyon Katsayısından yararlanılmıştır.

Sonuçlar yorumlanırken anlamlılık düzeyi olarak 0,05 kullanılmış olup; $\mathrm{p}<0,05$ olması durumunda anlamlı bir ilişkinin olduğu, $\mathrm{p}>0,05$ olması durumunda ise anlamlı bir ilişkinin olmadığ belirtilmiştir.

Bu çalışmada elde edilen veriler SPSS 20 paket programı ile analiz edilmiştir.

\section{Bulgular}

Çalışmanın örneklemine ilişkin demografik özelliklere ait bulgulara göre;

Araştırmaya alınan çocukların cinsiyete göre dağılımına bakıldığında çocukların \%50,8'inin kız, \%49,2'sinin de erkek çocuğu olduğu, kardeş sayısı dağ1lımına bakıldığında, çocukların \%34,76'sının kardeşinin olmadığı, \%65,24'nünün kardeşinin olduğu, doğum sirasına bakıldığında \%62,03'nünü ilk çocuk, \%9,89'nun ortanca çocuk, \%28,07 sinin son çocuk olduğu, babalarının öğrenim

14 Seviye Neslitürk, Nadir Çeliköz, "Okul Öncesi Değerler Ölçeği Aile ve Öğretmen Formunun Geçerlik ve Güvenirlik Çalışması”, Dicle Üniversitesi Ziya Gökalp Eğitim Fakültesi Dergisi, 24, 2015, s. 19-42. 
durumlarına bakıldığında, \%17,91'inin ilköğretim mezunu, \%37,17'sinin lise mezunu, \%8,56'sının ön lisans mezunu, \%29,14'ünün lisans mezunu, \%7,22'sinin lisansüstü mezunu olduğu, annelerinin öğrenim durumlarına bakıldığında, \%15,78'inin ilköğretim mezunu, \%38,24'ünün lise mezunu, \%12,03'ünün ön lisans mezunu, \%28,07'sinin lisans mezunu, \%5,88'sinin lisansüstü mezunu olduğu görülmüştür.

Sosyo-Ekonomik düzeye bakıldığında; ailelerin \%25.94'nün düşük gelir grubunda, \%47.06'sının orta gelir grubunda, \%27.01'nin yüksek gelir grubunda yer aldığ görülmüştür.

Araştırmaya alınan çocukların yaşlarının dağılımına bakıldığında 2012 doğumlu beş yaşında ve 2011 doğumlu altı yaşında olduğu görülmüştür. Araştırmaya alınan çocukların babasının tamamının 25-54 yaş aralığında olduğu, yaş ortalamasının 36,18 olduğu; çocukların annelerinin tamamının 23-50 yaş aralığında olduğu, yaş ortalamasının 33,09 olduğu görülmüsstür.

Araştırma örnekleminin farklı değişkenlerine ilişkin istatistik analizleri tablo 1-4 arasında verilmiştir.

Tablo 1. Araştırmaya Alınan Çocukların, Okul Öncesi Değerler Ölçeğinden Almış Oldukları Puanların Ortalamaları

\begin{tabular}{lllllll}
\hline & N & $\overline{\boldsymbol{x}}$ & Median & Min & Max & ss \\
\hline Sorumluluk & 374 & 6,33 & 7,00 & 2,00 & 9,00 & 1,67 \\
\hline Saygı & 374 & 7,01 & 7,00 & 2,00 & 10,00 & 1,77 \\
\hline İşbirliği & 374 & 7,56 & 8,00 & 2,00 & 10,00 & 1,37 \\
\hline Dürüstlük & 374 & 8,19 & 8,00 & 2,00 & 10,00 & 1,59 \\
\hline Dostluk/Arkadaşık & 374 & 9,32 & 10,00 & 3,00 & 10,00 & 0,99 \\
\hline Paylaşım & 374 & 8,38 & 9,00 & 1,00 & 10,00 & 1,73 \\
\hline Toplam & 374 & 46,79 & 48,00 & 25,00 & 57,00 & 5,76 \\
\hline
\end{tabular}

Tablo 1'de Okul Öncesi Değerler Ölçeği Ebeveyn formuyla ilgili yapılan analizler sonucunda: sorumluluk değerinin puan ortalamas 16,33 ; sayg değerinin puan ortalaması 7,01; işbirliği değerinin puan ortalaması 7,56; dürüstlük değerinin puan ortalaması 8,19 ; dostluk/arkadaşlık değerinin puan ortalaması 9,32; paylaşım değerinin puan ortalaması 8,38; Okul Öncesi Değerler Ölçeği toplam puan ortalaması 48,00 olduğu saptanmıştır. 
Aşağıda araştırmaya alınan çocukların, Okul Öncesi Değerler Ölçeğinden almış oldukları puanların ortalamalarının en düşükten en yükseğe doğru sıralandığı şekil verilmiştir.

\section{OKUL ÖNCESI DEĞERLER ÖLÇEĞi AILE FORMU PUAN ORTALAMALARI}

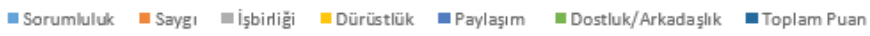

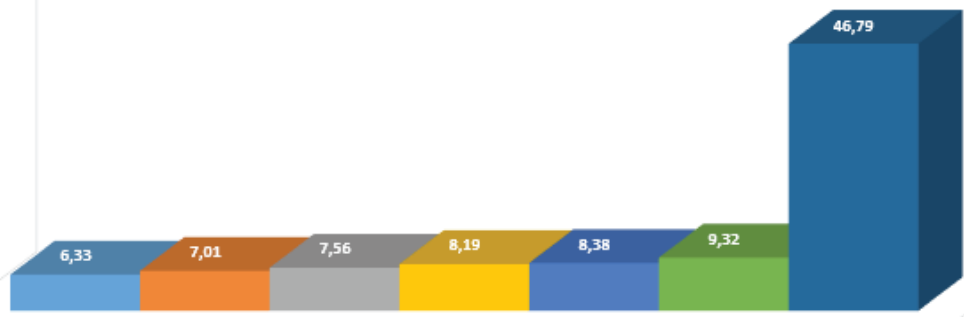

AILE FORMU PUAN ORTALAMALARI

Şekil 1. Araştırmaya alınan çocukların, Okul Öncesi Değerler Ölçeğinden almış oldukları puanların ortalamaları görülmektedir.

Şekil 1'de Okul Öncesi Değerler Ölçeğiyle ilgili puan ortalamaları en düşükten en yükseğe doğru sıralandığında; sorumluluk değerinin puan ortalaması 6,33 , sayg1 değerinin puan ortalamas 7,01 , işbirliği değerinin puan ortalamas 7,56 , dürüstlük değerinin puan ortalamas1 8,19 , paylaşım değerinin puan ortalaması 8,38, dostluk/arkadaşlık değerinin puan ortalaması 9,32, Okul Öncesi Değerler Ölçeği toplam puan ortalaması 46,79 olduğu saptanmıştır.

Tablo 2. Araştırmaya Alınan Çocukların Doğum Sırasına göre Okul Öncesi Değerler Ölçeğinden Almış Oldukları Puanların Kruskal Wallis H Testiyle Karşılaştırılması

\begin{tabular}{|c|c|c|c|c|c|c|c|c|c|c|}
\hline & \multicolumn{6}{|c|}{ Kaçıncı çocuk } & \multicolumn{3}{|c|}{$\begin{array}{c}\text { Kruskal Wallis } \\
\text { H Testi }\end{array}$} \\
\hline & & $\mathbf{N}$ & $\bar{x}$ & Median & Min & Max & Ss & $\begin{array}{l}\text { Sira } \\
\text { Ort. }\end{array}$ & $\mathbf{H}$ & $\mathbf{P}$ \\
\hline \multirow{4}{*}{ Sorumluluk } & $\begin{array}{l}\text { İlk } \\
\text { çocuk }\end{array}$ & 232 & 6,30 & 6,50 & 2,00 & 9,00 & 1,71 & 185,77 & \multirow{3}{*}{0,163} & \multirow{3}{*}{0,922} \\
\hline & $\begin{array}{l}\text { Ortanca } \\
\text { çocuk }\end{array}$ & 37 & 6,38 & 7,00 & 2,00 & 9,00 & 1,71 & 190,58 & & \\
\hline & $\begin{array}{l}\text { Son } \\
\text { çocuk }\end{array}$ & 105 & 6,37 & 7,00 & 3,00 & 9,00 & 1,58 & 190,24 & & \\
\hline & Toplam & 374 & 6,33 & 7,00 & 2,00 & 9,00 & 1,67 & & & \\
\hline
\end{tabular}




\begin{tabular}{|c|c|c|c|c|c|c|c|c|c|c|}
\hline \multirow{4}{*}{ Saygı } & $\begin{array}{l}\text { İlk } \\
\text { çocuk }\end{array}$ & 232 & 6,84 & 7,00 & 2,00 & 10,00 & 1,78 & 177,30 & \multirow{3}{*}{5,785} & \multirow{3}{*}{0,055} \\
\hline & $\begin{array}{l}\text { Ortanca } \\
\text { çocuk }\end{array}$ & 37 & 7,16 & 8,00 & 2,00 & 10,00 & 1,76 & 197,80 & & \\
\hline & $\begin{array}{l}\text { Son } \\
\text { çocuk }\end{array}$ & 105 & 7,32 & 7,00 & 2,00 & 10,00 & 1,70 & 206,41 & & \\
\hline & Toplam & 374 & 7,01 & 7,00 & 2,00 & 10,00 & 1,77 & & & \\
\hline \multirow{4}{*}{$\begin{array}{l}\text { İşbirliği } \\
\text { Puanı }\end{array}$} & $\begin{array}{l}\text { İlk } \\
\text { çocuk }\end{array}$ & 232 & 7,49 & 8,00 & 2,00 & 10,00 & 1,30 & 179,98 & \multirow{3}{*}{3,655} & \multirow{3}{*}{0,161} \\
\hline & $\begin{array}{l}\text { Ortanca } \\
\text { çocuk }\end{array}$ & 37 & 7,54 & 8,00 & 4,00 & 10,00 & 1,57 & 189,34 & & \\
\hline & $\begin{array}{l}\text { Son } \\
\text { çocuk }\end{array}$ & 105 & 7,73 & 8,00 & 4,00 & 10,00 & 1,45 & 203,47 & & \\
\hline & Toplam & 374 & 7,56 & 8,00 & 2,00 & 10,00 & 1,37 & & & \\
\hline \multirow{4}{*}{ Dürüstlük } & $\begin{array}{l}\text { İlk } \\
\text { çocuk }\end{array}$ & 232 & 8,06 & 8,00 & 4,00 & 10,00 & 1,58 & 177,29 & \multirow{3}{*}{6,166} & \multirow{3}{*}{0,054} \\
\hline & $\begin{array}{l}\text { Ortanca } \\
\text { çocuk }\end{array}$ & 37 & 8,52 & 9,00 & 5,00 & 10,00 & 1,40 & 214,38 & & \\
\hline & $\begin{array}{l}\text { Son } \\
\text { çocuk }\end{array}$ & 105 & 8,34 & 9,00 & 2,00 & 10,00 & 1,66 & 200,58 & & \\
\hline & Toplam & 374 & 8,19 & 8,00 & 2,00 & 10,00 & 1,59 & & & \\
\hline \multirow{4}{*}{$\begin{array}{l}\text { Dostluk / } \\
\text { Arkadaşlık }\end{array}$} & $\begin{array}{l}\text { İlk } \\
\text { çocuk }\end{array}$ & 232 & 9,31 & 10,00 & 3,00 & 10,00 & ,95 & 183,69 & \multirow{3}{*}{1,83} & \multirow{3}{*}{0,4} \\
\hline & $\begin{array}{l}\text { Ortanca } \\
\text { çocuk }\end{array}$ & 37 & 9,30 & 10,00 & 6,00 & 10,00 & ,94 & 180,95 & & \\
\hline & $\begin{array}{l}\text { Son } \\
\text { çocuk }\end{array}$ & 105 & 9,35 & 10,00 & 5,00 & 10,00 & 1,09 & 198,24 & & \\
\hline & Toplam & 374 & 9,32 & 10,00 & 3,00 & 10,00 & ,99 & & & \\
\hline \multirow{4}{*}{ Paylaşım } & $\begin{array}{l}\text { İlk } \\
\text { çocuk }\end{array}$ & 232 & 8,28 & 9,00 & 1,00 & 10,00 & 1,80 & 182,25 & \multirow{3}{*}{1,616} & \multirow{3}{*}{0,446} \\
\hline & $\begin{array}{l}\text { Ortanca } \\
\text { çocuk }\end{array}$ & 37 & 8,62 & 9,00 & 5,00 & 10,00 & 1,50 & 200,28 & & \\
\hline & $\begin{array}{l}\text { Son } \\
\text { çocuk }\end{array}$ & 105 & 8,50 & 9,00 & 2,00 & 10,00 & 1,67 & 194,60 & & \\
\hline & Toplam & 374 & 8,38 & 9,00 & 1,00 & 10,00 & 1,73 & & & \\
\hline \multirow{4}{*}{$\begin{array}{l}\text { Toplam } \\
\text { Puan }\end{array}$} & $\begin{array}{l}\text { İlk } \\
\text { çocuk }\end{array}$ & 232 & 46,28 & 47,00 & 28,00 & 57,00 & 5,67 & 176,48 & \multirow{3}{*}{6,513} & \multirow{3}{*}{0,039} \\
\hline & $\begin{array}{l}\text { Ortanca } \\
\text { çocuk }\end{array}$ & 37 & 47,59 & 49,00 & 34,00 & 57,00 & 5,07 & 199,64 & & \\
\hline & $\begin{array}{l}\text { Son } \\
\text { çocuk }\end{array}$ & 105 & 47,62 & 49,00 & 25,00 & 57,00 & 6,10 & 207,56 & & \\
\hline & Toplam & 374 & 46,79 & 48,00 & 25,00 & 57,00 & 5,76 & & & \\
\hline
\end{tabular}


Tablo 2'de Çocukların doğum sırasına göre Okul Öncesi Değerler Ölçeğinden almış oldukları puanların Kruskal Wallis H Testiyle karşılaştırılmasının sonuçları görülmektedir.

\section{Doğum sırasına göre yapılan analizler sonucunda;}

Okul Öncesi Değerler Ölçeği toplamında; ilk çocuklarda puan ortalaması 46,28; ortanca çocuklarda puan ortalaması 47,59; son çocuklarda puan ortalamas1 47,62 olduğu $(H=6,513 ; p=0,039 ; p<0,05)$ saptanmıştır. Gruplar aras1 karşılaştırmalarda Ortanca çocukların puanlarının İlk çocukların puanlarından anlamlı fark yaratacak düzeyde yüksek olduğu saptanmıştır $(\mathrm{p}<0.05)$. İlk çocuk ve son çocukların puanları arasında istatistik olarak anlamlı bir fark yoktur $(\mathrm{p}>0.05)$.

Araştırmaya alınan çocukların doğum sıralarının sorumluluk, saygı, işbirliği, dürüstlük, dostluk/arkadaşlık ve paylaşım değer puanları anlamlı bir fark yaratacak düzeyde olmadığı görülmüştür.

Tablo 3. Baba Öğrenim Durumunun, Araştırmaya Alınan Çocukların

Okul Öncesi Değerler Ölçeğinden Almış Oldukları Puanlarla Karşılaştırılması

(Kruskal Wallis H Testi)

\begin{tabular}{|c|c|c|c|c|c|c|c|c|c|c|}
\hline & \multicolumn{6}{|c|}{ Baba öğrenim } & \multicolumn{3}{|c|}{$\begin{array}{c}\text { Kruskal Wallis } \\
\text { H Testi }\end{array}$} \\
\hline & & $\mathbf{N}$ & $\bar{x}$ & Median & Min & Max & ss & $\begin{array}{l}\text { Sira } \\
\text { Ort. }\end{array}$ & $\mathbf{H}$ & $\mathbf{P}$ \\
\hline \multirow{6}{*}{ Sorumluluk } & İlköğretim & 67 & 6,10 & 6,00 & 3,00 & 9,00 & 1,73 & 174,09 & \multirow{5}{*}{2,556} & \multirow{5}{*}{0,635} \\
\hline & Lise & 139 & 6,36 & 7,00 & 2,00 & 9,00 & 1,75 & 191,27 & & \\
\hline & Ön lisans & 32 & 6,56 & 7,00 & 4,00 & 9,00 & 1,66 & 200,08 & & \\
\hline & Lisans & 109 & 6,41 & 7,00 & 2,00 & 9,00 & 1,53 & 191,51 & & \\
\hline & Lisansüstü & 27 & 6,11 & 6,00 & 3,00 & 9,00 & 1,69 & 170,26 & & \\
\hline & Toplam & 374 & 6,33 & 7,00 & 2,00 & 9,00 & 1,67 & & & \\
\hline \multirow{6}{*}{ Saygı } & İlköğretim & 67 & 6,43 & 7,00 & 2,00 & 10,00 & 1,95 & 155,46 & \multirow{5}{*}{$\begin{array}{l}9,075 \\
-\end{array}$} & \multirow{5}{*}{0,059} \\
\hline & Lise & 139 & 7,22 & 7,00 & 2,00 & 10,00 & 1,60 & 198,81 & & \\
\hline & Ön lisans & 32 & 6,81 & 7,00 & 3,00 & 10,00 & 1,86 & 175,34 & & \\
\hline & Lisans & 109 & 7,17 & 7,00 & 2,00 & 10,00 & 1,79 & 197,55 & & \\
\hline & Lisansüstü & 27 & 6,93 & 7,00 & 3,00 & 9,00 & 1,66 & 182,63 & & \\
\hline & Toplam & 374 & 7,01 & 7,00 & 2,00 & 10,00 & 1,77 & & & \\
\hline
\end{tabular}




\begin{tabular}{|c|c|c|c|c|c|c|c|c|c|c|}
\hline \multirow{6}{*}{ İşbirliği } & İlköğretim & 67 & 7,34 & 8,00 & 4,00 & 10,00 & 1,63 & 175,26 & \multirow{5}{*}{4,081} & \multirow{5}{*}{0,395} \\
\hline & Lise & 139 & 7,59 & 8,00 & 4,00 & 10,00 & 1,36 & 190,48 & & \\
\hline & Ön lisans & 32 & 7,41 & 7,00 & 3,00 & 10,00 & 1,43 & 169,72 & & \\
\hline & Lisans & 109 & 7,73 & 8,00 & 2,00 & 10,00 & 1,21 & 200,12 & & \\
\hline & Lisansüstü & 27 & 7,44 & 8,00 & 4,00 & 10,00 & 1,28 & 172,67 & & \\
\hline & Toplam & 374 & 7,56 & 8,00 & 2,00 & 10,00 & 1,37 & & & \\
\hline \multirow{6}{*}{ Dürüstlük } & İlköğretim & 67 & 7,79 & 8,00 & 4,00 & 10,00 & 1,65 & 159,99 & \multirow{5}{*}{6,583} & \multirow{5}{*}{0,16} \\
\hline & Lise & 139 & 8,23 & 9,00 & 3,00 & 10,00 & 1,60 & 190,94 & & \\
\hline & Ön lisans & 32 & 8,28 & 9,00 & 4,00 & 10,00 & 1,67 & 196,02 & & \\
\hline & Lisans & 109 & 8,40 & 9,00 & 5,00 & 10,00 & 1,43 & 199,82 & & \\
\hline & Lisansüstü & 27 & 8,00 & 8,00 & 2,00 & 10,00 & 1,84 & 178,22 & & \\
\hline & Toplam & 374 & 8,19 & 8,00 & 2,00 & 10,00 & 1,59 & & & \\
\hline \multirow{6}{*}{$\begin{array}{l}\text { Dostluk / } \\
\text { Arkadaşlık }\end{array}$} & İlköğretim & 67 & 9,04 & 9,00 & 5,00 & 10,00 & 1,11 & 158,75 & \multirow{5}{*}{8,032} & \multirow{5}{*}{0,09} \\
\hline & Lise & 139 & 9,38 & 10,00 & 5,00 & 10,00 & ,96 & 194,59 & & \\
\hline & Ön lisans & 32 & 9,31 & 9,50 & 7,00 & 10,00 &, 86 & 179,56 & & \\
\hline & Lisans & 109 & 9,43 & 10,00 & 7,00 & 10,00 & ,82 & 196,09 & & \\
\hline & Lisansüstü & 27 & 9,30 & 10,00 & 3,00 & 10,00 & 1,44 & 197,11 & & \\
\hline & Toplam & 374 & 9,32 & 10,00 & 3,00 & 10,00 & ,99 & & & \\
\hline \multirow{6}{*}{ Paylaşım } & İlköğretim & 67 & 7,70 & 8,00 & 1,00 & 10,00 & 2,10 & 151,89 & \multirow{5}{*}{8,032} & \multirow{5}{*}{0,09} \\
\hline & Lise & 139 & 8,41 & 9,00 & 1,00 & 10,00 & 1,73 & 189,13 & & \\
\hline & Ön lisans & 32 & 8,22 & 8,00 & 5,00 & 10,00 & 1,66 & 174,31 & & \\
\hline & Lisans & 109 & 8,81 & 9,00 & 5,00 & 10,00 & 1,37 & 212,26 & & \\
\hline & Lisansüstü & 27 & 8,33 & 9,00 & 3,00 & 10,00 & 1,75 & 183,15 & & \\
\hline & Toplam & 374 & 8,38 & 9,00 & 1,00 & 10,00 & 1,73 & & & \\
\hline \multirow{6}{*}{$\begin{array}{l}\text { Toplam } \\
\text { Puan }\end{array}$} & İlköğretim & 67 & 44,42 & 44,00 & 28,00 & 56,00 & 6,34 & 145,23 & \multirow{5}{*}{14,806} & \multirow{5}{*}{0,005} \\
\hline & Lise & 139 & 47,19 & 48,00 & 25,00 & 57,00 & 5,56 & 195,08 & & \\
\hline & Ön lisans & 32 & 46,59 & 47,00 & 28,00 & 57,00 & 5,74 & 181,84 & & \\
\hline & Lisans & 109 & 47,95 & 49,00 & 35,00 & 57,00 & 4,92 & 207,22 & & \\
\hline & Lisansüstü & 27 & 46,11 & 47,00 & 26,00 & 57,00 & 6,96 & 180,46 & & \\
\hline & Toplam & 374 & 46,79 & 48,00 & 25,00 & 57,00 & 5,76 & & & \\
\hline
\end{tabular}


Tablo 3'de Babalarının öğrenim durumunun araştırmaya alınan çocukların Okul Öncesi Değerler Ölçeğinden almış oldukları puanlarının Kruskal Wallis H Testiyle karşılaştırılmasının sonuçları görülmektedir.

Babalarının Öğrenim Durumuyla ilgili yapılan analizler sonucunda;

Paylaşım değerinin; ilköğretim mezunu olan babaların çocuklarının puan ortalaması 7,70; lise mezunu olan babaların çocuklarının puan ortalaması 8,41 ; önlisans mezunu olan babaların çocuklarının puan ortalaması 8,22 ; lisans mezunu olan babaların çocuklarının puan ortalaması 8,81 ; lisansüstü mezunu olan babaların çocuklarının puan ortalamasının 8,33 ; olduğu $(\mathrm{H}=14,404 ; \mathrm{p}=0,006 ; \mathrm{p}<0,05)$ saptanmıştır. Gruplar arası karşılaştırmalarda babası lise ve lisans mezunu çocukların puanları ilköğretim mezunu olan babaların çocuklarının puanlarından anlamlı fark yaratacak düzeyde yüksek olduğu saptanmıştır $(\mathrm{p}<0.05)$. Lise, önlisans, lisans ve lisansüstü mezunu babaların çocuklarının puanları arasında istatistik olarak anlamlı bir fark yoktur $(\mathrm{p}>0.05)$.

Okul Öncesi Değerler Ölçeği toplamında; ilköğretim mezunu olan babaların çocuklarının puan ortalaması 44,42; Lise mezunu olan babaların çocuklarının puan ortalaması 47,19; önlisans mezunu olan babaların çocuklarının puan ortalaması 46,59 ; lisans mezunu olan babaların çocuklarının puan ortalaması 47,95; lisansüstü mezunu olan babaların çocuklarının puan ortalamasının 46,11 ; olduğu $(H=14,806 ; p=0,005 ; p<0,05)$ saptanmıştır. Gruplar arası karşılaştırmalarda babası lise ve lisans mezunu çocukların puanları ilköğretim mezunu olan babaların çocuklarının puanlarından anlamlı fark yaratacak düzeyde yüksek olduğu saptanmıştır $(\mathrm{p}<0.05)$. önlisans, lisans ve lisansüstü mezunu babaların çocuklarının puanları arasında istatistik olarak anlamlı bir fark yoktur $(\mathrm{p}>0.05)$.

Araştırmaya alınan çocukların babalarının öğrenim durumuyla sorumluluk, sayg1, işbirliği, dürüstlük ve dostluk/arkadaşlık değer puanları anlamlı bir fark yaratacak düzeyde olmadığ 1 görülmüştür. 
Tablo 4. Anne Öğrenim Durumunun, Araştırmaya Alınan Çocukların Okul Öncesi Değerler Ölçeğinden Almış Oldukları Puanlarla Karşılaştırılması (Kruskal Wallis H Testi)

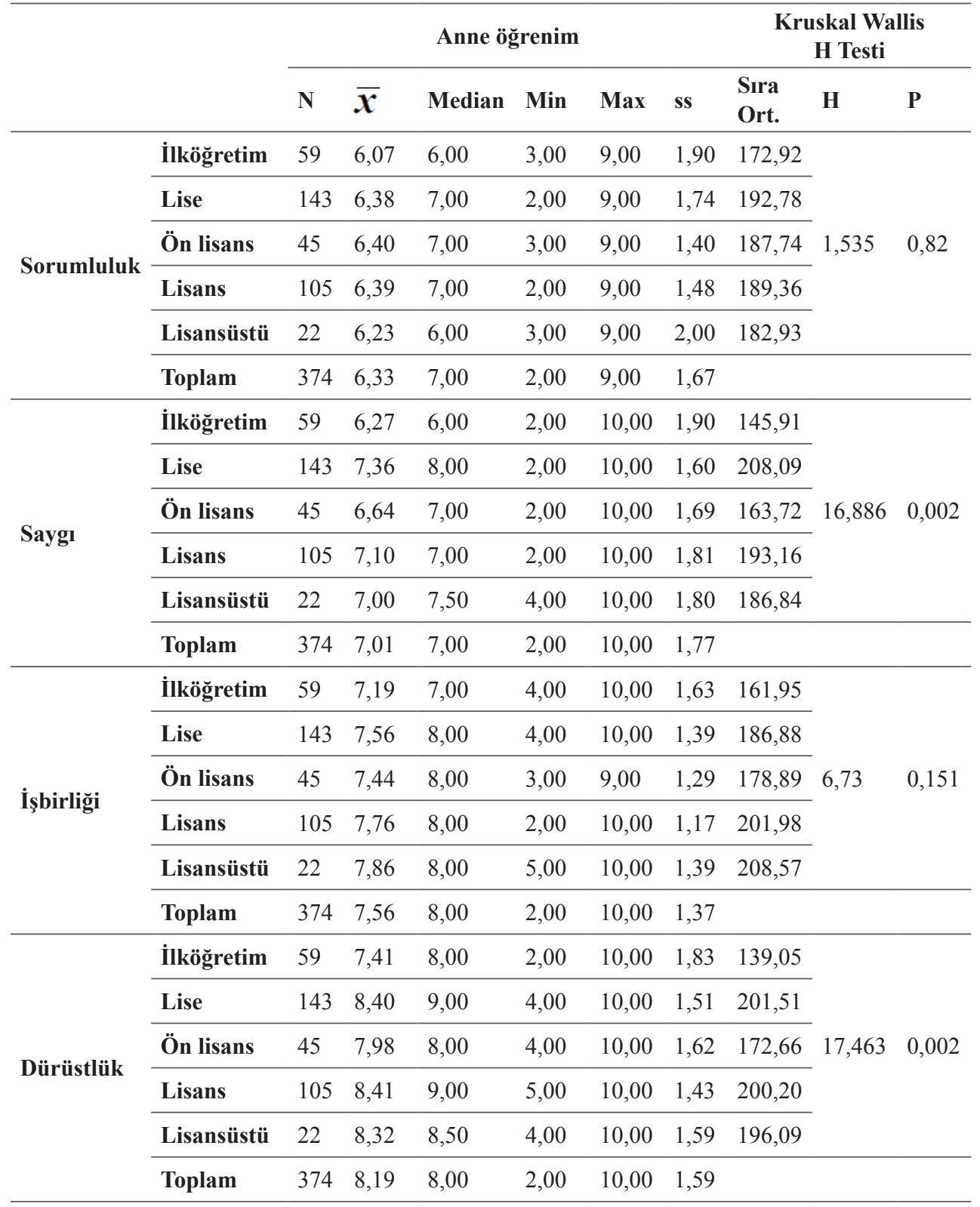




\begin{tabular}{|c|c|c|c|c|c|c|c|c|c|c|}
\hline \multirow{6}{*}{$\begin{array}{l}\text { Dostluk / } \\
\text { Arkadaşlık }\end{array}$} & İlköğretim & 59 & 9,00 & 9,00 & 5,00 & 10,00 & 1,16 & 156,49 & \multirow{5}{*}{8,005} & \multirow{5}{*}{0,091} \\
\hline & Lise & 143 & 9,46 & 10,00 & 7,00 & 10,00 &, 77 & 197,48 & & \\
\hline & Ön lisans & 45 & 9,33 & 10,00 & 6,00 & 10,00 & ,93 & 185,53 & & \\
\hline & Lisans & 105 & 9,31 & 10,00 & 3,00 & 10,00 & 1,09 & 189,73 & & \\
\hline & Lisansüstü & 22 & 9,32 & 10,00 & 5,00 & 10,00 & 1,25 & 199,18 & & \\
\hline & Toplam & 374 & 9,32 & 10,00 & 3,00 & 10,00 & ,99 & & & \\
\hline \multirow{6}{*}{ Paylaşım } & İlköğretim & 59 & 7,75 & 8,00 & 1,00 & 10,00 & 2,08 & 154,31 & \multirow{5}{*}{8,281} & \multirow{5}{*}{0,082} \\
\hline & Lise & 143 & 8,38 & 9,00 & 1,00 & 10,00 & 1,71 & 187,23 & & \\
\hline & Ön lisans & 45 & 8,60 & 9,00 & 2,00 & 10,00 & 1,66 & 201,68 & & \\
\hline & Lisans & 105 & 8,56 & 9,00 & 3,00 & 10,00 & 1,54 & 196,20 & & \\
\hline & Lisansüstü & 22 & 8,68 & 9,00 & 5,00 & 10,00 & 1,62 & 207,70 & & \\
\hline & Toplam & 374 & 8,38 & 9,00 & 1,00 & 10,00 & 1,73 & & & \\
\hline \multirow{6}{*}{$\begin{array}{l}\text { Toplam } \\
\text { Puan }\end{array}$} & İlköğretim & 59 & 43,68 & 43,00 & 26,00 & 57,00 & 6,80 & 135,29 & \multirow{5}{*}{17,386} & \multirow{5}{*}{0,002} \\
\hline & Lise & 143 & 47,55 & 49,00 & 32,00 & 56,00 & 4,97 & 199,59 & & \\
\hline & Ön lisans & 45 & 46,40 & 48,00 & 25,00 & 57,00 & 6,08 & 182,62 & & \\
\hline & Lisans & 105 & 47,53 & 48,00 & 32,00 & 57,00 & 5,42 & 200,50 & & \\
\hline & Lisansüstü & 22 & 47,41 & 48,50 & 36,00 & 57,00 & 6,08 & 196,82 & & \\
\hline & Toplam & 374 & 46,79 & 48,00 & 25,00 & 57,00 & 5,76 & & & \\
\hline
\end{tabular}

Tablo 4'te Annelerin öğrenim durumunun araştırmaya alınan Çocukların Okul Öncesi Değerler Ölçeğinden almış oldukları puanlarının Kruskal Wallis H Testiyle karşılaştırılmasının sonuçları görülmektedir.

Annelerin öğrenim durumuyla ilgili yapılan analizler sonucunda;

Sayg1 değerinin; ilköğretim mezunu olan annelerin çocuklarının puan ortalaması 6,27; lise mezunu olan annelerin çocuklarının puan ortalaması 7,36; önlisans mezunu olan annelerin çocuklarının puan ortalaması 6,64; lisans mezunu olan annelerin çocuklarının puan ortalaması 7,10; lisansüstü mezunu olan annelerin çocuklarının puan ortalamasının 7,00; olduğu $(H=16,886 ; p=0,002 ; p<0,05)$ saptanmıştır. Gruplar arası karşılaştırmalarda annesi lise, lisans ve lisansüstü mezunu çocukların puanları, ilköğretim mezunu olan annelerin çocuklarının puanlarından anlamlı fark yaratacak düzeyde yüksek olduğu saptanmıştır ( $\mathrm{p}<0.05)$. lise, önlisans, lisans ve lisansüstü mezunu annelerin çocuklarının puanları arasında istatistik olarak anlamlı bir fark yoktur $(\mathrm{p}>0.05)$. 
Dürüstlük değerinin; ilköğretim mezunu olan annelerin çocuklarının puan ortalamas 1,41; Lise mezunu olan annelerin çocuklarının puan ortalaması 8,40; önlisans mezunu olan annelerin çocuklarının puan ortalamas 17,98; lisans mezunu olan annelerin çocuklarının puan ortalamas 18,41 ; lisansüstü mezunu olan annelerin çocuklarının puan ortalamasının 8,32 ; olduğu $(H=17,463 ; p=0,002 ; p<0,05)$ saptanmıştır. Gruplar arası karşılaştırmalarda annesi lise, lisans ve lisansüstü mezunu çocukların puanları, ilköğretim mezunu olan annelerin çocuklarının puanlarından anlamlı fark yaratacak düzeyde yüksek olduğu saptanmıştır $(\mathrm{p}<0.05)$. lise, önlisans, lisans ve lisansüstü mezunu annelerin çocuklarının puanları arasında istatistik olarak anlamlı bir fark yoktur ( $\mathrm{p}>0.05)$.

Okul Öncesi Değerler Ölçeği toplamında; ilköğretim mezunu olan annelerin çocuklarının puan ortalaması 43,68; lise mezunu olan annelerin çocuklarının puan ortalaması 47,55; önlisans mezunu olan annelerin çocuklarının puan ortalaması 46,40; lisans mezunu olan annelerin çocuklarının puan ortalaması 47,53; lisansüstü mezunu olan annelerin çocuklarının puan ortalamasının 47,41; olduğu $(\mathrm{H}=17,386 ; \mathrm{p}=0,002 ; \mathrm{p}<0,05)$ saptanmıştır. Gruplar arası karşılaştırmalarda annesi lise, önlisans, lisans ve lisansüstü mezunu çocukların puanları, ilköğretim mezunu olan annelerin çocuklarının puanlarından anlamlı fark yaratacak düzeyde yüksek olduğu saptanmıştır ( $\mathrm{p}<0.05)$. lise, önlisans, lisans ve lisansüstü mezunu annelerin çocuklarının puanları arasında istatistik olarak anlamlı bir fark yoktur ( $>0.05)$.

Araştırmaya alınan çocukların annelerinin öğrenim durumuyla sorumluluk, işbirliği, ve dostluk/arkadaşlık ve paylaşım değer puanları anlamlı bir fark yaratacak düzeyde olmadığı görülmüştür.

Tablo 5. Sosyo Ekonomik Düzeyle, Araştırmaya Alınan Çocukların Okul Öncesi Değerler Ölçeğinden Almış Oldukları Puanların Kruskal Wallis H Testiyle Karşılaştırılması

\begin{tabular}{|c|c|c|c|c|c|c|c|c|c|c|}
\hline & & \multicolumn{6}{|c|}{ Sosyo Ekonomik Düzey } & \multicolumn{3}{|c|}{$\begin{array}{c}\text { Kruskal Wallis } \\
\text { H Testi }\end{array}$} \\
\hline & & $\mathbf{N}$ & $\bar{x}$ & Median & Min & Max & ss & $\begin{array}{l}\text { Sira } \\
\text { Ort. }\end{array}$ & $\mathbf{H}$ & $\mathbf{P}$ \\
\hline \multirow{4}{*}{ Sorumluluk } & Düşük & 97 & 6,26 & 7,00 & 2,00 & 9,00 & 1,89 & 185,59 & \multirow{3}{*}{1,114} & \multirow{3}{*}{0,573} \\
\hline & Orta & 176 & 6,42 & 7,00 & 2,00 & 9,00 & 1,62 & 193,18 & & \\
\hline & Yüksek & 101 & 6,24 & 6,00 & 3,00 & 9,00 & 1,54 & 179,45 & & \\
\hline & Toplam & 374 & 6,33 & 7,00 & 2,00 & 9,00 & 1,67 & & & \\
\hline
\end{tabular}




\begin{tabular}{|c|c|c|c|c|c|c|c|c|c|c|}
\hline \multirow{4}{*}{ Saygı } & Düşük & 97 & 6,37 & 6,00 & 2,00 & 10,00 & 1,98 & 152,05 & \multirow{3}{*}{15,502} & \multirow{3}{*}{0,001} \\
\hline & Orta & 176 & 7,29 & 7,00 & 2,00 & 10,00 & 1,63 & 204,73 & & \\
\hline & Yüksek & 101 & 7,12 & 7,00 & 2,00 & 10,00 & 1,64 & 191,53 & & \\
\hline & Toplam & 374 & 7,01 & 7,00 & 2,00 & 10,00 & 1,77 & & & \\
\hline \multirow{4}{*}{$\begin{array}{l}\text { İşbirliği } \\
\text { Puanı }\end{array}$} & Düşük & 97 & 7,21 & 7,00 & 4,00 & 10,00 & 1,59 & 165,86 & \multirow{3}{*}{5,779} & \multirow{3}{*}{0,056} \\
\hline & Orta & 176 & 7,65 & 8,00 & 2,00 & 10,00 & 1,34 & 193,09 & & \\
\hline & Yüksek & 101 & 7,74 & 8,00 & 5,00 & 10,00 & 1,13 & 198,55 & & \\
\hline & Toplam & 374 & 7,56 & 8,00 & 2,00 & 10,00 & 1,37 & & & \\
\hline \multirow{4}{*}{ Dürüstlük } & Düşük & 97 & 7,71 & 8,00 & 2,00 & 10,00 & 1,78 & 158,28 & \multirow{3}{*}{10,423} & \multirow{3}{*}{0,005} \\
\hline & Orta & 176 & 8,31 & 9,00 & 3,00 & 10,00 & 1,53 & 194,65 & & \\
\hline & Yüksek & 101 & 8,45 & 9,00 & 4,00 & 10,00 & 1,42 & 203,10 & & \\
\hline & Toplam & 374 & 8,19 & 8,00 & 2,00 & 10,00 & 1,59 & & & \\
\hline \multirow{4}{*}{$\begin{array}{l}\text { Dostluk / } \\
\text { Arkadaşlık }\end{array}$} & Düşük & 97 & 9,16 & 9,00 & 5,00 & 10,00 & 1,04 & 169,71 & \multirow{3}{*}{9,102} & \multirow{3}{*}{0,011} \\
\hline & Orta & 176 & 9,34 & 10,00 & 6,00 & 10,00 &, 87 & 184,24 & & \\
\hline & Yüksek & 101 & 9,46 & 10,00 & 3,00 & 10,00 & 1,12 & 210,26 & & \\
\hline & Toplam & 374 & 9,32 & 10,00 & 3,00 & 10,00 & ,99 & & & \\
\hline \multirow{4}{*}{ Paylaşım } & Düşük & 97 & 7,65 & 8,00 & 1,00 & 10,00 & 2,09 & 147,60 & \multirow{3}{*}{19,796} & \multirow{3}{*}{0,001} \\
\hline & Orta & 176 & 8,57 & 9,00 & 3,00 & 10,00 & 1,54 & 197,17 & & \\
\hline & Yüksek & 101 & 8,74 & 9,00 & 3,00 & 10,00 & 1,47 & 208,97 & & \\
\hline & Toplam & 374 & 8,38 & 9,00 & 1,00 & 10,00 & 1,73 & & & \\
\hline \multirow{4}{*}{$\begin{array}{l}\text { Toplam } \\
\text { Puan }\end{array}$} & Düşük & 97 & 44,36 & 45,00 & 25,00 & 56,00 & 6,64 & 146,85 & \multirow{3}{*}{18,656} & \multirow{3}{*}{0,001} \\
\hline & Orta & 176 & 47,57 & 48,00 & 28,00 & 57,00 & 5,11 & 200,44 & & \\
\hline & Yüksek & 101 & 47,74 & 49,00 & 32,00 & 57,00 & 5,29 & 204,00 & & \\
\hline & Toplam & 374 & 46,79 & 48,00 & 25,00 & 57,00 & 5,76 & & & \\
\hline
\end{tabular}

Tablo 5'te Sosyo Ekonomik Düzeyle, araştırmaya alınan çocukların Okul Öncesi Değerler Ölçeğinden almış oldukları puanların Kruskal Wallis H Testiyle karşılaştırılmasının sonuçları görülmektedir.

Sosyo-Ekonomik düzeyle ilgili yapılan analizler sonucunda;

Sayg1 değerinin; düşük gelir grubunda yer alan çocuklarda puan ortalaması 6,37; orta gelir grubunda yer alan çocuklarda puan ortalaması 7,29; yüksek gelir grubunda yer alan çocuklarda puan ortalaması 7,12 olduğu $(H=15,502 ; p=0,001$; 
$\mathrm{p}<0,05)$ saptanmıştır. Gruplar arası karşılaştırmalarda yüksek ve orta gelir grubunda olan çocukların puanlarının düşük gelir grubunda yer alan çocukların puanlarından anlamlı fark yaratacak düzeyde yüksek olduğu saptanmıştır $(p<0.05)$. Orta ve yüksek gelir grubundaki çocukların puanları arasında istatistik olarak anlamlı bir fark yoktur $(p>0.05)$.

Dürüstlük değerinin; düşük gelir grubunda yer alan çocuklarda puan ortalaması 7,71; orta gelir grubunda yer alan çocuklarda puan ortalaması 8,45 ; yüksek gelir grubunda yer alan çocuklarda puan ortalaması 8,19 olduğu $(H=10,423$; $\mathrm{p}=0,005 ; \mathrm{p}<0,05)$ saptanmıştır. Gruplar arası karşılaştırmalarda yüksek ve orta gelir grubunda olan çocukların puanlarının düşük gelir grubunda yer alan çocukların puanlarından anlamlı fark yaratacak düzeyde yüksek olduğu saptanmıştır $(p<0.05)$. Yüksek ve orta gelir grubundaki çocukların puanları arasında istatistik olarak anlamlı bir fark yoktur $(\mathrm{p}>0.05)$.

Dostluk/Arkadaşlık değerinin; düşük gelir grubunda yer alan çocuklarda puan ortalamas 18,56 ; orta gelir grubunda yer alan çocuklarda puan ortalaması 9,34; yüksek gelir grubunda yer alan çocuklarda puan ortalamas 19,46 olduğu $(\mathrm{H}=9,102 ; \mathrm{p}=0,011 ; \mathrm{p}<0,05)$ saptanmıştır. Gruplar arası karşılaştırmalarda Yüksek ve orta gelir grubunda olan çocukların puanlarının düşük gelir grubunda yer alan çocukların puanlarından anlamlı fark yaratacak düzeyde yüksek olduğu saptanmıştır $(\mathrm{p}<0.05)$. Yüksek ve orta gelir grubundaki çocukların puanları arasında istatistik olarak anlamlı bir fark yoktur ( $>00.05)$.

Paylaşım değerinin; düşük gelir grubunda yer alan çocuklarda puan ortalamas1 7,65; orta gelir grubunda yer alan çocuklarda puan ortalamas1 8,57; yüksek gelir grubunda yer alan çocuklarda puan ortalaması 8,74 olduğu $(H=19,796 ; p=0,001$; $\mathrm{p}<0,05)$ saptanmıştır. Gruplar arası karşılaştırmalarda yüksek ve orta gelir grubunda olan çocukların puanlarının düşük gelir grubunda yer alan çocukların puanlarından anlamlı fark yaratacak düzeyde yüksek olduğu saptanmıştır $(p<0.05)$. Yüksek ve orta gelir grubundaki çocukların puanları arasında istatistik olarak anlamlı bir fark yoktur ( $>00.05)$.

Okul Öncesi Değerler Ölçeği toplamında; düşük gelir grubunda yer alan çocuklarda puan ortalamas1 44,36; orta gelir grubunda yer alan çocuklarda puan ortalamas1 47,57; yüksek gelir grubunda yer alan çocuklarda puan ortalaması 47,74 olduğu $(H=18,656 ; p=0,001 ; p<0,05)$ saptanmıştır. Gruplar arası karş1laştırmalarda yüksek ve orta gelir grubunda olan çocukların puanlarının düşük gelir grubunda yer alan çocukların puanlarından anlamlı fark yaratacak düzeyde yüksek olduğu saptanmıştır ( $\mathrm{p}<0.05)$. Yüksek ve orta gelir grubundaki çocukların puanları arasında istatistik olarak anlamlı bir fark yoktur $(\mathrm{p}>0.05)$. 
Araştırmaya alınan çocukların ailelerinin sosyo ekonomik durumuyla çocukların sorumluluk ve işbirliği değer puanları arasında anlamlı bir fark yaratacak düzeyde olmadığ 1 görülmüştür.

Tablo 6. Araştırmaya Alınan Çocukların Okul Öncesi Değerler Ölçeğinden Almış Oldukları Puanlar İle Ebeveyn ve Çocukların Yaşı Arasındaki İlişsiye Dair Spearman's Korelasyon Testi Sonuçları

\begin{tabular}{|c|c|c|c|c|}
\hline & & Çocuk Yaş & Baba Yaş & Anne Yaş \\
\hline \multirow{3}{*}{ Sorumluluk } & $\mathbf{r}$ & 0,032 & $-0,036$ & $-0,023$ \\
\hline & $\mathbf{p}$ & 0,54 & 0,482 & 0,657 \\
\hline & $\mathbf{n}$ & 374 & 374 & 374 \\
\hline \multirow{3}{*}{ Saygı } & $\mathbf{r}$ & $0,155^{* *}$ & 0,063 & 0,079 \\
\hline & $\mathbf{p}$ & 0,003 & 0,225 & 0,128 \\
\hline & $\mathbf{n}$ & 374 & 374 & 374 \\
\hline \multirow{3}{*}{ İşbirliğgi } & $\mathbf{r}$ & $0,105^{*}$ & 0,1 & $\mathbf{0 , 1 3 3 * *}$ \\
\hline & $\mathbf{p}$ & 0,043 & 0,054 & 0,01 \\
\hline & $\mathbf{n}$ & 374 & 374 & 374 \\
\hline \multirow{3}{*}{ Dürüistlük } & $\mathbf{r}$ & $0,120 *$ & 0,049 & 0,081 \\
\hline & $\mathbf{p}$ & 0,02 & 0,349 & 0,119 \\
\hline & $\mathbf{n}$ & 374 & 374 & 374 \\
\hline \multirow{3}{*}{$\begin{array}{l}\text { Dostluk/Arkadaş- } \\
\text { lık }\end{array}$} & $\mathbf{r}$ & $0,121 *$ & 0,052 & $0,131^{*}$ \\
\hline & $\mathbf{p}$ & 0,019 & 0,319 & 0,011 \\
\hline & $\mathbf{n}$ & 374 & 374 & 374 \\
\hline \multirow{3}{*}{ Paylaşım } & $\mathbf{r}$ & $0,175^{* *}$ & 0,079 & 0,085 \\
\hline & $\mathbf{p}$ & 0,001 & 0,126 & 0,1 \\
\hline & $\mathbf{n}$ & 374 & 374 & 374 \\
\hline \multirow{3}{*}{ Toplam Puan } & $\mathbf{r}$ & $0,19 * *$ & 0,077 & $0,109^{*}$ \\
\hline & $\mathbf{p}$ & 0 & 0,138 & 0,035 \\
\hline & $\mathbf{n}$ & 374 & 374 & 374 \\
\hline
\end{tabular}

Tablo 6'da Araştırmaya alınan çocukların Okul Öncesi Değerler Ölçeğinden almış oldukları puanlar ile Ebeveyn ve Çocukların Yaşı Arasındaki İlişkiye Dair Spearman's Korelasyon Testi Analizi Sonuçları görülmektedir. 
Yapılan analizler sonucunda;

Çocukların yaşı ile saygı değeri puanı arasında istatistiksel olarak anlamlı ilişki bulunmaktadır $(\mathrm{p}<0,05)$. Bu ilişki ters yönlü ve zayıftır $(\mathrm{r}=0,155)$. Çocukların yaşı arttıkça saygı değeri puanı da artmaktadır.

Çocukların yaşı ile işbirliği değeri puanı arasında istatistiksel olarak anlamlı ilişki bulunmaktadır $(\mathrm{p}<0,05)$. Bu ilişki ters yönlü ve zayıftır $(\mathrm{r}=0,105)$. Çocukların yaşı arttıkça işbirliği değeri puanı da artmaktadır.

Annelerin yaşı ile işbirliği değeri puanı arasında istatistiksel olarak anlamlı ilişki bulunmaktadır $(\mathrm{p}<0,05)$. Bu ilişki ters yönlü ve zayıftır $(\mathrm{r}=0,133)$. Annelerin yaşı arttıkça işbirliği değeri puanı da artmaktadır.

Çocukların yaşı ile dürüstlük değeri puanı arasında istatistiksel olarak anlamlı ilişki bulunmaktadır $(\mathrm{p}<0,05)$. Bu ilişki ters yönlü ve zayıftır $(\mathrm{r}=0,120)$. Çocukların yaşı arttıkça dürüstlük değeri puanı da artmaktadır.

Çocukların yaşı ile Dostluk/Arkadaşlık değeri puanı arasında istatistiksel olarak anlamlı ilişki bulunmaktadır $(\mathrm{p}<0,05)$. Bu ilişki ters yönlü ve zayıftır $(\mathrm{r}=0,121)$. Çocukların yaşı arttıkça Dostluk/Arkadaşlık değeri puanı da artmaktadır.

Annelerin yaşı ile Dostluk/Arkadaşlık değeri puanı arasında istatistiksel olarak anlamlı ilişki bulunmaktadır ( $\mathrm{p}<0,05)$. Bu ilişki ters yönlü ve zayıftır $(\mathrm{r}=0,131)$. Annelerin yaşı arttıkça Dostluk/Arkadaşlık değeri puanı da artmaktadır.

Çocukların yaşı ile Okul Öncesi Değerler Ölçeği toplam puanı arasında istatistiksel olarak anlamlı ilişki bulunmaktadır $(\mathrm{p}<0,05)$.. Bu ilişki ters yönlü ve zayıftır $(\mathrm{r}=0,19)$. Çocukların yaşı arttıkça Okul Öncesi Değerler Ölçeği toplam puanı da artmaktadır.

Annelerin yaşı ile Okul Öncesi Değerler ölçeği toplam puanı arasında istatistiksel olarak anlamlı ilişki bulunmaktadır $(\mathrm{p}<0,05)$.. Bu ilişki ters yönlü ve zayıftır $(r=0,19)$. Annelerin yaşı arttıkça Okul Öncesi Değerler Ölçeği toplam puanı da artmaktadır.

Okul Öncesi Değerler Ölçeği'in alt ölçekleri ve toplam puanlarıyla baba yaşı arasında istatistiksel olarak anlamlı ilişki bulunmamaktadır.

\section{Tartışma, Sonuç ve Öneriler}

$\mathrm{Bu}$ araştırmada okul öncesi eğitim kurumlarına devam eden beş-altı yaş çocukların ebeveyn görüşlerine göre değer düzeylerinin belirlenmesi amaçlanmıştır. Elde edilen verilerin analizinde; frekans, yüzde, aritmetik ortalama gibi betimsel 
istatistiklerin yanı sıra, araştırmanın amaçlarını test etmek amacıyla uygun istatistik programı ile analiz edilmiştir.

Ebeveyn görüşlerine göre anaokuluna devam eden çocukların değer düzeylerinin belirlenmesi çalışmasının sonuçlarına göre, cinsiyet dağılımının dengeli olduğu, çocukların çoğunlukla ilk çocuk olduğu, çocukların babalarının çoğunlukla lise mezunu ve lisans mezunu olduğu, çocukların annelerinin çoğunlukla lise mezunu ve lisans mezunu olduğu, çocukların babasının yaş ortalamasının 36,18 olduğu; çocukların annelerinin yaş ortalamasının 33,09 olduğu görülmüştür.

Araştırmaya alınan çocukların, Okul Öncesi Değerler Ölçeğinden almış oldukları puanlara göre çocukların sırasıyla en fazla dostluk/arkadaşlık, paylaşım, dürüstlük, işbirliği, sayg1 ve sorumluluk değerlerini edindikleri görülmektedir. Araştırma bulguları paralelinde Bonnic ${ }^{15}$ tarafindan yapılan çalışmada ise okul öncesi dönemde uygulanacak olan karakter eğitim programında, sayg1, sorumluluk ve iş birliği gibi değerleri ele almıştır. Dilmaç, Kulaksızoğlu ve Eksi ${ }^{16}$ tarafından yapılan araştırmada, İnsanî Değerler Eğitimi Programının, öğrencilerin değerleri kazanma düzeylerini incelemişlerdir. Araştırma sonuçlarına göre; deney grubunda yer alan öğrencilerin sorumluluk, dostluk/arkadaşlık, sayg1, dürüstlük, hoşgörü değerlerinde anlamlı bir farklılık olduğu saptanmıştır. Çetingöz ${ }^{17}$ tarafından yapılan çalışmada okul öncesi öğretmen adayları değer olarak kazandırılabilecek kavramlar olarak en yüksek sıklıkta saygı, sevgi, hoşgörü, arkadaşlık, iş birliği ve empati değerini vurgulamışlardır. Erikli ${ }^{18}$ tarafından yapılan çalışmada; anasınıfına devam eden 5-6 yaş çocukları için hazırlanan okul öncesi değerler eğitimi programının çocukların saygı, sorumluluk, dürüstlük, iş birliği, paylaşım ve arkadaşlık değerlerine olan etkisini incelendiği araştırma sonucunda, okul öncesi değerler eğitimi programının deney grubu çocukların saygı, iş birliği, dürüstlük, arkadaşlık, ve paylaşma ile ilgili değerlerinde etkili olduğu saptanmıştır.

15 F. Bonnic, A Caring and Sharing Environment Helps Teach Values in Kindergarten Students, Master's Action Reseach Project, Saint Xavier University And Skylight Professional Development Field Based Master's Programme, 2000.

16 Bülent Dılmaç,- Adnan Kulaksizoğlu, Halil Ekşl1, "An Examination of the Humane Values Education Program on a Group of Science High School Students”, Educational Sciences: Theory \& Practice, 2007.

17 Duygu Çetingöz, "Okul Öncesi Eğitimi Öğretmen Adaylarının Değerler Eğitiminde Öğretmenin Rolüne İlişkin Görüşleri”, Türkiye Sosyal Araştırmalar Dergisi, 19 (3), 2015, s. 33-52.

18 Sultan Erikli, "Okul Öncesi Çocukları İçin Bir Değerler Eğitimi Programının Geliştirilmesi ve Uygulanması”, (Yayınlanmamış Yüksek Lisans Tezi), Orta Doğu Teknik Üniversitesi Sosyal Bilimler Enstitüsü, Ankara, 2016. 
Ogelman ve Sarıkaya ${ }^{19}$ tarafından yapılan araştırmada okul öncesi öğretmenlerinin okul öncesi dönem çocuklarına kazandırılması gereken ilk üç değer sıralamasında, saygı, sorumluluk, sevgi olduğunu, Yazar ve Erkuş ${ }^{20}$ tarafından yapılan araştırmada okul öncesi öğretmenleri öncelikle saygı değerlerinin çocuklara verilmesi gerektiğini, Alpöge ${ }^{21}$ ve Dinç ${ }^{22}$, okul öncesi dönemde çocuklara öz sayg1, öz denetim, sorumluluk, işbirliği, sevgi, sayg1, dürüstlük ve sabır gibi değerlerin kazandırılabileceğini belirtmiştir. Sapsağlam'ın yapmış olduğu çalışmada çocukların sorumluluk değerini kazanabildikleri23, Uyanık Balat, Özdemir Beceren ve Özdemir Adak ${ }^{24}$ tarafından yapılan araştırmada ebeveynler çocuklarının sahip olmasını istedikleri evrensel değerleri sırasıyla dürüstlük, sorumluluk, sayg1, mutluluk, adalet, merhamet ve güvenilirlik, iyi vatandaş olma ve barış şeklinde sıralamışlardır.

Araştırma bulgularından ve yapılan araştırmalardan görüldüğü gibi, en düşük puan ortalaması sorumluluk, saygı, işbirliği ve dürüstlük değerlerine aittir. Araştırma alanyazında çocuklara kazandırılabilecek ve kazandırılması zor olan değerlerle ilgili yapılan çalışmalarla büyük ölçüde uyum göstermektedir. Şahin'in anaokuluna devam eden beş ve altı çocuklarının sahip oldukları değerleri öğretmen görüşlerine göre incelediği çalışmasında, çocukların en az edindikleri değer dürüstlük değeri olarak tespit etmiştir. Yapılan bu çalışma okul öncesi değer ölçeği aile formundan aldığımız sonuçlarla benzerlik göstermektedir. ${ }^{25}$

19 Hülya Gülay Ogelman - Hatice Sarıkaya, “Okul Öncesi Eğitimi Öğretmenlerinin Değerler Eğitimi Konusundaki Görüşleri: Denizli İli Örneği”, Sakarya Üniversitesi Eğitim Fakültesi Dergisi, (29), 2015, s.81-100.

20 Taha Yazar - Süreyya Erkuş, “Okul Öncesi Öğretmenlerinin Okul Öncesi Eğitim Programındaki Değerler Eğitimine İlişkin Görüşlerinin Değerlendirilmesi”, Dicle Üniversitesi Ziya Gökalp Eğitim Fakültesi Dergisi, 20, 2013, s. 196 - 211.

21 G. Alpöge, Okulöncesinde Değerler Ĕ̆itimi, İstanbul, Bilgi Yayınevi, 2011.

22 Berrin Dinç, Okulöncesi Dönemde Değerler Ĕgitiminin Yeri ve Önemi, editör Arzu Arıkan. Okulöncesi Dönemde Değerler Ĕ̆itimi, Eskişehir, Anadolu Üniversitesi Web-Ofset Tesisi, 2011, s.149-164.

23 Özkan Sapsağlam, “Okul Öncesi Dönem Çocuklarının Değer Algılarının Çizdikleri Resimler ve Sözlü Anlatımlarına Göre İncelenmesi: Sorumluluk Değeri Örneği”, Eğitim ve Bilim, 42 (189), 2017, s. 287-303.

24 Gülden Uyanık Balat - B. B. Özdemir - Ö. A. Adak “The Evaluation Of Parents' Views Related to Helping Pre-School Children Gain Some Universal Values", Procedia Social and Behavioral Sciences, (15), 2011, s. 908-912.

25 Hakan Şahin, "Resmi Anaokuluna Devam Eden Çocukların Öğretmen Görüşlerine Göre Sahip Oldukları Değer Düzeylerinin Belirlenmesi”, Turkish Studies Dergisi, 12/28, 2017, s. 663-680. 
Çocukların doğum sırasına göre yapılan analizler sonucunda; Okul Öncesi Değerler Ölçeği toplamında; ortanca çocukların puanlarının İlk çocukların puanlarından anlamlı fark yaratacak düzeyde yüksek olduğu saptanmıştır. İlk çocuk ve son çocukların puanları arasında istatistik olarak anlamlı bir fark yoktur. Ortanca çocuklar ilk çocukları gözlemleyerek ve modelleyerek değer edindiklerinden kaynaklanabilir. Ayrıca ebeveynlerinde ikinci sonraki çocuklarda tecrübelendikleri söylenebilir.

Babaların öğrenim durumuyla ilgili yapılan analizler sonucunda; paylaşım değeri ve Okul Öncesi Değerler Ölçeği toplamında babası lise ve lisans mezunu çocukların puanları İlköğretim mezunu olan babaların çocuklarının puanlarından anlamlı fark yaratacak düzeyde yüksek olduğu saptanmıştır. önlisans, lisans ve lisansüstü mezunu babaların çocuklarının puanları arasında istatistik olarak anlamlı bir fark yoktur. Annelerin öğrenim durumuyla ilgili yapılan analizler sonucunda; sayg1, dürüstlük değeri ve Okul Öncesi Değerler Ölçeği toplamında annesi lise ve lisans ve Lisansüstü mezunu çocukların puanları, ilköğretim mezunu olan annelerin çocuklarının puanlarından anlamlı fark yaratacak düzeyde yüksek olduğu saptanmıştır. Lise, önlisans, lisans ve lisansüstü mezunu annelerin çocuklarının puanları arasında istatistik olarak anlamlı bir fark yoktur. Eskicumalı ve Eroğlu'nun yapmış oldukları çalışmada, anne ve babaların eğitim düzeyleri çocukların davranış ve tutumlarında etkili olduğu görülmüştür. Sonuç olarak, eğitim seviyesi yükseldikçe annelerin ve babaların çocuklarına karşı daha olumlu ve bilinçli tutumlar sergiledikleri söylenebilir. ${ }^{26}$ Hatunoğlu, Halmatov ve Hatunoğlu'nun ailelerin sosyo kültürel ve ekonomik durumlarına göre okul öncesi dönemdeki çocukların ahlaki ve sosyal kural bilgilerinin farklılaşıp farklılaşmadığını belirlemek amacıyla yapmış oldukları araştırmada, sosyo kültürel ve eğitim düzeyi düşük ve yüksek olan ailelerin çocuklarının ahlaki kural bilgisi alt boyutlarının tümünde yüksek olanların lehine anlamlı farklılık çıktığı görülmüştür. Yani sosyo ekonomik ve eğitim düzeyi yüksek ailelerin çocuklarının ahlaki kural bilgisi düşük olan gruba göre daha iyi durumdadır. ${ }^{27}$

Sosyo-Ekonomik düzeyle ilgili yapılan analizler sonucunda; Saygı, dürüstlük, paylaşım değeri ve Okul Öncesi Değerler Ölçeği toplamında; yüksek ve orta gelir grubunda olan çocukların puanlarının, düşük gelir grubunda yer alan çocuk-

26 Ahmet Eskicumal - Erol Eroğlu, "Ailenin Sosyo-Ekonomik ve Eğitim Düzeyleri İle Çocukların Problem Çözme Yetenekleri Arasındaki İlişki”, Sakarya Üniversitesi Eğitim Fakültesi Dergisi, (1), 2001.

27 Aşkım Hatunoglu - Medera Halmatov - B. Yavuz Hatunoglu, Ailelerin Sosyo Ekonomik Düzeylerine Göre Okul Öncesi Dönemdeki Çocukların Ahlaki ve Sosyal Kural Bilgilerinin Incelenmesi, 2012. 
ların puanlarından anlamlı fark yaratacak düzeyde yüksek olduğu saptanmıştır. Orta ve yüksek gelir grubundaki çocukların puanları arasında istatistik olarak anlamlı bir fark yoktur.

Yaka, Yalçın ve Denizli'nin ${ }^{28}$ velilerinin, okul öncesi eğitimde verilecek öncelikli değerlere ilişkin görüşlerini inceledikleri çalışmalarında, sosyo-ekonomik düzeyi orta ve yüksek olan velilerin dürüst olma ve sorumluluk sahibi olma değerlerine düşük, sosyo-ekonomik düzeydeki velilerden daha çok önemsedikleri görülmüştür. Sayg1lı olma değerinde ise orta sosyo-ekonomik düzey velileri üst ve alt sosyo-ekonomik düzey velilerinden puanları yüksek çıkmıştır. Tatlı ve Güngöraytar ${ }^{29}$, tarafından yapılan araştırma sonucuna göre paylaşmak, yardımseverlik, merhamet, sevgi, hoşgörü, vatanseverlik, iyilik, tutumluluk ve dürüstlük değerlerine ilişkin çocukların çizdikleri resimlerinin ve buna yönelik açıklamalarının birçoğunun değerin gerçek anlamına uygun olduğu görülmüştür. Araştırmamızın sonuçlarına göre paylaşma değerini kolaylıkla kazanabildikleri görülmüştür. Okul öncesi değer ölçeği aile formuna göre en fazla edindikleri ikinci değer paylaşma değeri olduğu gözlenmiştir. Bakan' $n^{30}$ yapmış olduğu çalışmada, anasınıfına devam eden 5-6 yaş çocukları için hazırlanan Okul Öncesi Değerler Eğitim Programının çocukların saygı, sorumluluk, dürüstlük, iş birliği, paylaşım ve arkadaşlık değerlerine olan etkisini aile ve öğretmen görüşlerine göre incelenmesi amaçlanmış, araştırma sonucunda; Okul Öncesi Değerler Eğitim Programının çocukların değer kazanımlarını olumlu yönde etkilediği görülmüştür.

Çocukların yaşı arttıkça saygı, dürüstlük değeri ve Okul Öncesi Değerler Ölçeği toplam puanı da artmaktadır. Çocukların gelişimsel olarak yaşları ile doğru orantılı olarak değer düzeylerinin de artması beklenmektedir.

Annelerin yaşı arttıkça işbirliği değeri puanı da artmaktadır. Annelerin yaşı arttıkça Dostluk/Arkadaşlık değeri puanı da artmaktadır. Annelerin yaşı arttıkça Okul Öncesi Değerler Ölçeği toplam puanı da artmaktadır. Annelerin yaş düzeyleri arttıkça tecrübe düzeylerinin daha fazla olduğu düşünülmektedir. Bu doğrultuda da çocukların değer edinmelerinde pozitif yönde katlı sağladığı, değer kazanımlarını olumlu yönde etkilediği söylenebilir.

28 Şenol Yaka - Demet Yalçın - Esin Denizli, “Okul Öncesi Eğitimde Verilecek Öncelikli Değerlere İlişkin Veli Görüşleri”, Değerler Ĕgitimi Dergisi, cilt 12, no 28, , 2014, s. 169- 192.

29 Sümeyya Tatlı - Güngör Aytar, "Okul Öncesi Dönem Çocuklarinin Değerlere Ilişkin Algilari Ve Bunlari Ifade Etme Biçimlerinin İncelenmesi”, Türkiye Sosyal Araştırmalar Dergisi, (2), 2017, s.331-354.

30 Tuba Bakan, "Değerler eğitim programının anasınıfına devam eden çocuklarının değer kazanımları üzerine etkisinin incelenmesi”, (Yayınlanmamış Yüksek Lisans Tezi), İstanbul Üniversitesi Eğitim Bilimleri Enstitüsü, İstanbul, 2018. 
$\mathrm{Bu}$ sonuçlar doğrultusunda; değerler eğitim programları hazırlanarak çocukların değer düzeyleri arttırılabilir. Programındaki etkinliklere değer kazanımlarını destekleyici örnekler etkinlikler konabilir. Ebeveynlere yönelik eğitim programları hazırlanarak çocukların değer düzeylerinin artmasına katkı sağlanabilir. Daha geniş bir grupla değer düzeyleri ve değer edinim düzeylerini etkileyen faktörler belirlenebilir. Parçalanmış ve parçalanmamış ailelerin çocuklarının değer edinimleri karşılaştırılabilir. Aile katılımı da program içine alınarak eğitim desteklenebilir. 


\section{Kaynakça}

Acun, İ., Yücel, C., Önder, A. \& Tarman, B., “Değerler: Kim Ne Kadar Değer Veriyor?”, Uşak Üniversitesi Sosyal Bilimler Dergisi, (12), 2013.

Alpöge, G., Okulöncesinde Değerler Eğitimi, İstanbul, Bilgi Yayınevi, 2011.

Aydın, M. Z., "Ailede Ahlak Eğitimi”, Cumhuriyet Üniversitesi İlahiyat Fakültesi Dergisi, cilt VII 1 2, 2003.

Bakan, T., "Değerler Eğitim Programının Anasınıfına Devam Eden Çocuklarının Değer Kazanımları Üzerine Etkisinin İncelenmesi”, (Yayınlanmamış Yüksek Lisans Tezi), İstanbul Üniversitesi Eğitim Bilimleri Enstitüsü, İstanbul, 2018.

Balat, G. U., Yalçın A., Yemenici, F., Sabancı, H., Kalaycı, K.K., Halisdemir, M., Bakülü, N., Hazar, R. G., Köse, S., Ünsal, Y., Okul Öncesinde Değerler Eğitimi ve Etkinlik Örnekleri, Ankara, Pegem Akademi, 2012.

Bonnic, F., A Caring and Sharing Environment Helps Teach Values in Kindergarten Students, Master's Action Reseach Project, Saint Xavier University And Skylight Professional Development Field Based Master's Programme, 2000.

Çankırılı, A., Ailede ve Okulda Değerler Ĕ̌itimi, İstanbul, Zafer Yayınları, 2015.

Çetingöz, D., “Okul Öncesi Eğitimi Öğretmen Adaylarının Değerler Eğitiminde Öğretmenin Rolüne İlişkin Görüşleri”, Türkiye Sosyal Araştırmalar Dergisi, 19 (3), 2015.

Ekşi, H., "Temel İnsani Değerlerin Kazandırılmasında Bir Yaklaşım: Karakter Eğitimi Programları”, Değerler Ĕgitimi Dergisi, 1(1), 2003.

Eskicumalı, A., ve Eroğlu, E., “Ailenin Sosyo-Ekonomik ve Eğitim Düzeyleri İle Çocukların Problem Çözme Yetenekleri Arasındaki İlişki”, Sakarya Üniversitesi Eğitim Fakültesi Dergisi, (1), 2014.

Erikli, S., "Okul Öncesi Çocukları İçin Bir Değerler Eğitimi Programının Geliştirilmesi ve Uygulanması”, (Yayınlanmamış Yüksek Lisans Tezi), Orta Doğu Teknik Üniversitesi Sosyal Bilimler Enstitüsü, Ankara, 2016.

Güngör, E., Değerler Psikolojisi, Amsterdam, Hollanda Türk Akademisyenler Birliği Vakfı Yayınları, 1993.

Hatunoglu, A., Halmatov, M., \& Hatunoglu, B. Y., "Ailelerin Sosyo Ekonomik Düzeylerine Göre Okul Öncesi Dönemdeki Çocukların Ahlaki Ve Sosyal Kural Bilgilerinin İncelenmesi”, Akademik Bakış Dergisi, 32, 2012. 
Karasar, N., Bilimsel Araştırma Metodu, Ankara, Hacetepe Taş Kitapçılık, 1984.

Kutlutürk, G., Din Kültürü ve Ahlak Bilgisi 2 Ders Notu, Ankara, MEB Hayat Boyu Öğrenme Genel Müdürlüğü Yayınları, 2012.

Neslitürk S., Çeliköz N., "Okul Öncesi Değerler Ölçeği aile ve öğretmen formunun geçerlik ve güvenirlik çalışması”, Dicle Üniversitesi Ziya Gökalp Eğitim Fakültesi Dergisi, cilt 24, 2015.

Ogelman, G. H. \& Sarıkaya, E. H., "Okul Öncesi Eğitimi Öğretmenlerinin Değerler Eğitimi Konusundaki Görüşleri: Denizli İli Örneği”, Sakarya Üniversitesi Ĕ̌itim Fakültesi Dergisi, (29), 2015.

Sapsağlam, Ö., Okul Öncesi Dönemde Karakter ve Değerler Eğitimi, editör Prof. Dr. Esra Ömeroğlu, Ankara, Pegem Akademi Yayınları, 2016.

, "Okul Öncesi Dönem Çocuklarının Değer Algılarının Çizdikleri Resimler ve Sözlü Anlatımlarına Göre İncelenmesi: Sorumluluk Değeri Örneği”, Eğitim ve Bilim, 42 (189), 2017.

Şahin, H., "Resmi Anaokuluna Devam Eden Çocukların Öğretmen Görüşlerine Göre Sahip Oldukları Değer Düzeylerinin Belirlenmesi”, Turkish Studies Dergisi, 12/28, 2017.

Tatl1, S., Aytar, F. A. G., "Okul Öncesi Dönem Çocuklarının Değerlere İlişkin Algıları ve Bunları Ífade Etme Biçimlerinin İncelenmesi”, Türkiye Sosyal Araştırmalar Dergisi, (2), 2017.

Tekşan, K., "Türkçe Dersi Değerler Eğitiminde Kutadgu Bilig'in Kullan1mı”, Ahi Evran Üniversitesi Kırşehir Eğitim Fakültesi Dergisi, 13 (3), 2012.

Uyanık, Balat, G., Özdemir Beceren, B. \& Adak Özdemir, A., "The Evaluation of Parents' Views Related To Helping Pre-School Children Gain Some Universal Values", Procedia Social and Behavioral Sciences, (15) 2011.

Yaka, Ş., Yalçın, D. \& Denizli, E., "Okul Öncesi Eğitimde Verilecek Öncelikli Değerlere İlişkin Veli Görüşleri”, Değerler Eğitimi Dergisi, cilt 12, no 28, 2014.

Yazar, T., \& Erkuş, S., “Okul Öncesi Öğretmenlerinin Okul Öncesi Eğitim Programındaki Değerler Eğitimine İlişkin Görüşlerinin Değerlendirilmesi”, Dicle Üniversitesi Ziya Gökalp Eğitim Fakültesi Dergisi, 20, 2013.

Yılmaz, H., "Çocuğun Ailede Kazanacağı Önemli Bir Değer: Kanaatkârlık", Ĕ̈itime Bakış Dergisi, (18), 2010.

Yörükoğlu, A., Çocuk Ruh Sağlı̆̆g, 5. basım, İstanbul, Türkiye İş Bankası Kültür Yayınları, 1983. 